\title{
THE ELECTROLYSIS OF ACID SOLUTIONS OF ANILINE
}

\section{BY LACHIAN GILCHRIST}

When hydrochloric acid is electrolyzed, chlorine is set free at the anode, and it seemed quite feasible to dissolve a little aniline in the acid and let it be converted into chlor-aniline by the chlorine set free, just as the soda in the electrolysis of salt solutions is converted into hypochlorite.

Accordingly, a solution of $\mathrm{Io} \mathrm{g}$ of aniline, $50 \mathrm{cc}$ of hydrochloric acid s. g. I.2, and $50 \mathrm{cc}$ water was made up, and a current of 30 amperes was passed through it, using pieces of platinum foil $2 \times 5 \mathrm{~cm}$ as electrodes. It was not thought necessary to keep the aniline away from the cathode, as the chlor-aniline, once formed, is not easily reduced.

\section{Formation of aniline black}

In a few minutes, however, a greenish smudge appeared at the anode and soon spread through the liquid. As this was obviously due to the formation of "aniline black" (one of the oxidation products of aniline) and meant an impure product and a bad yield, the experiment was broken off.

It is well known that in the electrolysis of hydrochloric acid oxygen is often given off together with the chlorine, the proportion depending on the concentration of the acid and on the current density. It therefore seemed possible that by reducing the latter and increasing the former the chlorine evolved might be more nearly pure, and the formation of the oxidation product prevented.

The attempt was made in the next electrolysis, in which $1 / 2$ amp was passed through a solution of $5 \mathrm{~g}$ of freshly distilled aniline in $100 \mathrm{cc}$ of hydrochloric acid of s. g. I.2; but aniline black was formed as before. Four other experiments carried out under different conditions of current density and concentration gave the same result. In Experiment 6 a little mannite 
was added to the solution to prevent oxidation, but without effect.

TABLE I

\begin{tabular}{|c|c|c|c|c|c|}
\hline No. & $\mathrm{HCl}$ s.g. I.2 & Aniline & Water & Current & Temp. \\
\hline I & $50 \mathrm{cc}$ & $\log$ & $50 \mathrm{cc}$ & $30 \mathrm{amp}$ & I $8^{\circ}-37^{\circ}$ \\
\hline 2 & $100 \mathrm{cc}$ & $5 \mathrm{~g}$ & - & $\mathrm{I} / 2 \mathrm{amp}$ & I $8^{\circ}-23^{\circ}$ \\
\hline 3 & $100 \mathrm{cc}$ & $5 \mathrm{~g}$ & - & $27 \mathrm{amp}$ & $30^{\circ}-40^{\circ}$ \\
\hline 4 & $100 \mathrm{cc}$ & small amt & - & $1 / 2$ amp & $25^{\circ}$ \\
\hline 5 & IOO CC & small amt & - & $\mathrm{I} / / 2 \mathrm{amp}$ & $24^{\circ}-10^{\circ}$ \\
\hline 6 & $100 \mathrm{cC}$ & $\mid \begin{array}{c}\text { IOg of } \mathrm{HCl} \\
\text {-aniline }\end{array}$ & IO CC & $\mathrm{I} / 2 \mathrm{amp}$ & $\begin{array}{l}10^{\circ} \\
\text { (in ice) }\end{array}$ \\
\hline
\end{tabular}

Determination of decomposition-voltage

The formation of aniline black in all these cases raised the question whether after all this substance might not be the primary product of the electrolysis; to test this point preparations

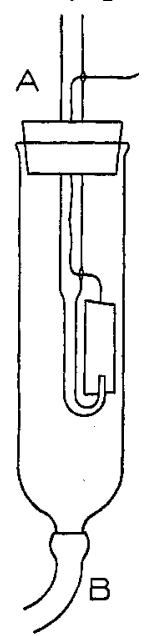
were made to determine the decomposition-voltage of the solution.

The apparatus differed but slightly from that used by other investigators in measuring decomposition-voltages. The cathode cell is represented in Fig. $\mathrm{I}$, hydrogen was led in by $\mathrm{A}$, and the connection with the anode compartment was effected through the narrow rubber tube $\mathrm{B}(25 \mathrm{~cm}$ long, $3 \mathrm{~mm}$ internal diameter.)

The first experiments were made with normal hydrochloric acid, and a good deal of trouble was experienced in obtaining accordant results. After a number of trials, however, it was found that:-

(i) Electrolytic hydrogen must be used in place Fig. I of hydrogen from zinc and sulphuric acid.

(ii) The anode should be cleaned before each experiment, by treatment with hot nitric acid and water, then heated to red heat, then again washed with hot nitric acid, water, and alcohol, and dried in the air. 
(iii) Changing the length of the anode wire from $2.5 \mathrm{~mm}$ to I mm has but little effect on the results.

(iv) Platinizing the anode wire has but little effect.

(v) Covering it with a glass tube, so as to reduce the volume of the anode compartment, has but little effect.

(vi) Shaking the anode has only a temporary effect; but the solution must not mix with the cathode solution.

(vii) The measurements should be taken with rising E. M. F. If taken in the opposite direction the cell must be short-circuited between measurements, and then at least ten minutes must be allowed for the galvanometer to reach a steady state.

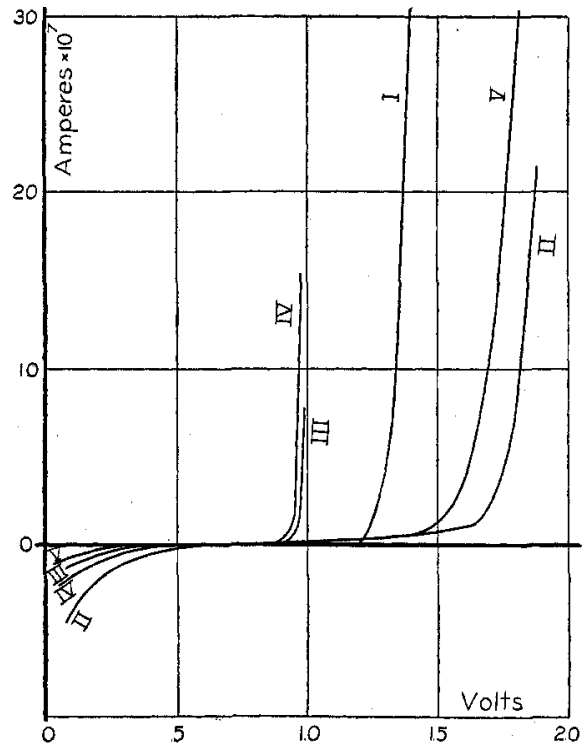

Fig. 2

If these points be attended to, fairly satisfactory measure ments can be made; and the galvanometer comes to its final position within two to ten minutes from the time of changing the voltage.

The results of the work with hydrochloric acid are given in Table 2 and Curve I (Fig. 2). The curve rises suddenly at I.25 volts; this is the well known "chlorine kink;" at lower voltages no chlorine is liberated from the solution. The result with 
normal sulphuric acid is given in Table 3 and Curve II (page 54I). The curve here rises suddenly at about $\mathrm{I} .66$ volts as is also well known.

TABI, 2

Normal Hydrochloric Acid

\begin{tabular}{c|r||l|r}
\hline \hline Volts & $\begin{array}{c}\text { Amperes } \\
\times 10^{7}\end{array}$ & Volts & $\begin{array}{c}\text { Amperes } \\
\times 10^{7}\end{array}$ \\
\hline 1.18 & -0.2 & 1.308 & +6.3 \\
1.213 & +0.6 & 1.33 & 8.0 \\
1.241 & 1.2 & 1.35 & 10.5 \\
1.265 & 2.8 & 1.38 & 21.2 \\
1.288 & 4.2 & 1.4 & 41.5
\end{tabular}

TABLE 3

Normal Sulphuric Acid

\begin{tabular}{l|c|c|c|c|c}
\hline \hline Volts & $\begin{array}{c}\text { Amperes } \\
\times 10^{7}\end{array}$ & Volts & $\begin{array}{c}\text { Amperes } \\
\times \mathrm{IO}^{7}\end{array}$ & Volts & $\begin{array}{c}\text { Amperes } \\
\times 10^{7}\end{array}$ \\
\hline 0.036 & 4.25 & 0.58 & -0.08 & 1.208 & +0.127 \\
0.148 & 3.66 & 0.638 & 0.04 & 1.23 & $0.15 \mathrm{I}$ \\
0.172 & 3.08 & 0.668 & 0.03 & 1.272 & 0.191 \\
0.21 & 2.72 & 0.743 & 0.005 & 1.307 & 0.218 \\
0.25 & 1.37 & 0.84 & +0.028 & 1.334 & 0.28 \\
0.319 & 0.87 & 0.876 & 0.043 & 1.46 & 0.41 \\
0.36 & 0.69 & 0.943 & 0.058 & 1.493 & 0.98 \\
0.421 & 0.61 & 1.005 & 0.07 & 1.659 & 1.18 \\
0.484 & 0.38 & I.139 & 0.093 & 1.786 & 6.12 \\
0.546 & 0.27 & I.176 & 0.109 & 1.875 & 21.2
\end{tabular}

Aniline hydrochloride was then dissolved in the normal hydrochloric acid in the proportion of one-tenth molecule per liter, and the measurements repeated. It was quite impossible to obtain a steady reading on the galvanometer, as the current kept falling for several hours after the voltage was applied (see Table 4). The same is true of solutions of aniline in normal sulphuric acid (see Table 5). 
In these experiments of long duration the formation of aniline black at the anode could be observed; that this was not due to oxidation by the air is shown by a blank experiment in which air was blown through the same solution in presence of a piece of platinum for 48 hours without causing the slightest turbidity or coloration.

TABLE 4

Normal Hydrochloric Acid and Tenth-Normal Aniline

\begin{tabular}{c|c|c}
\hline Volts & Amperes $\times 10^{7}$ & Time \\
\hline 2 & -0.042 & $4 \mathrm{~min}$. \\
4 & -0.018 & $6 \mathrm{\prime}$ \\
4 & -0.02 & $4 \mathrm{hrs}$. \\
6 & +0.002 & $6 \mathrm{~min}$. \\
6 & -0.009 & $16 \mathrm{hrs}$. \\
6 & -0.008 & $5 \mathrm{~min}$. \\
8 & +0.03 & $6 \mathrm{~min}$. \\
8 & -0.002 & $3 \mathrm{hrs}$.
\end{tabular}

TABLE 5

Normal Sulphuric Acid and Tenth-Normal Aniline

\begin{tabular}{|c|c|c|}
\hline Volts & Amperes $\times 10^{7}$ & Time \\
\hline IO & -0.34 & $4 \mathrm{~min}$. \\
\hline IO & 0.63 & I9 hrs. \\
\hline I 5 & 0.12 & \\
\hline 19 & 0.62 & Io $\min$. \\
\hline I9 & $0.3^{8}$ & 34 \\
\hline 19 & 0.015 & $20 \mathrm{hrs}$. \\
\hline 22 & $2.7^{2}$ & $50 \mathrm{~min}$. \\
\hline 22 & I. 5 & 2 days \\
\hline 24 & 6. 18 & $4 \mathrm{~min}$. \\
\hline 24 & 3.67 & I I $/ 2$ hrs. \\
\hline 24 & $3 \cdot 3$ & $\mathrm{I} / 2 \mathrm{hr}$. \\
\hline 27 & IO.O & 7 min. \\
\hline
\end{tabular}

Dark greenish smudge commenced to form

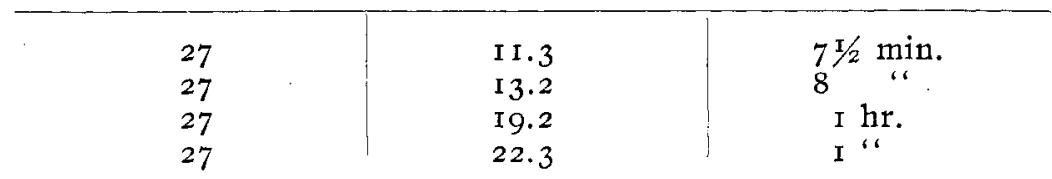


The cell was again filled with the aniline acid solution, hydrogen passed in at the large electrodes as before, the primary circuit broken at $\mathrm{Y}$, and the current and E. M. F. determined. Both rose steadily until the current reached $\mathrm{I} .4 \times \mathrm{IO}^{-7}$ amp and the E. M.F. V = 0.0I 2 volt, after which the voltage fell, the current increased, and aniline black appeared in the anode solution.

From these experiments it is clear that a definite current for each voltage is not to be expected; the figures given in Table 6 and plotted in Curve III were therefore arbitrarily taken four minutes after adjusting the E. M. F. The sudden rise in the curve occurs at 0.95 volt, 0.30 volt below the chlorine kink. This shows that the aniline acts as a "depolarizer" in hydrochloric acid solution, but whether owing to the formation of a chlor-aniline, or of aniline black, does not appear.

TABLE 6

Normal Hydrochloric Acid and Tenth-Normal Aniline

\begin{tabular}{l|c|c|c|c|c}
\hline Volts & $\begin{array}{c}\text { Amperes } \\
\times \text { I0 }\end{array}$ & Volts & $\begin{array}{c}\text { Amperes } \\
\times \text { IO }^{7}\end{array}$ & Volts & $\begin{array}{c}\text { Amperes } \\
\times \mathrm{IO}^{7}\end{array}$ \\
\hline 0.029 & $-\mathrm{I} .7$ & 0.432 & -0.01 & 0.739 & +0.01 \\
0.099 & $\mathrm{I} .33$ & 0.472 & 0.002 & 0.784 & 0.01 \\
0.19 & 0.54 & 0.485 & 0.000 & 0.84 & 0.014 \\
0.264 & $0.2 \mathrm{I}$ & 0.535 & +0.004 & 0.91 & 0.055 \\
0.328 & 0.08 & 0.569 & 0.006 & 0.936 & 0.2 \\
0.368 & 0.05 & 0.609 & 0.006 & 0.971 & 1.37 \\
0.403 & 0.02 & 0.664 & 0.007 & 0.988 & 4.3
\end{tabular}

Decomposition voltages in sulphuric acid solutions

A set of measurements was then made under the same conditions as those of Table 4 , but using normal sulphuric acid and one-tenth mol of aniline sulphate per liter, instead of the hydrochloric acid and the chloride. The results are contained in Table 7 and Curve IV.

Curve IV has its kink at the same voltage (0.95 volt) as Curve III for the experiments in which hydrochloric acid was used. The simplest explanation is that in both cases the same product is formed; in absence of hydrochloric acid this can not 
be chlor-aniline; it must therefore be an oxidation product, presumably the aniline black.

With this difference of 0.30 volt in favor of the oxidation, it seems very unlikely that any chlorine could be liberated in hydrochloric acid to which aniline had been added. By increasing the current density at the anode sufficiently, however, it might be possible to oxidize the aniline at that electrode more quickly than it could be replaced by convection or diffusion; so that, for part of the time, the solution would consist of pure hydrochloric acid, and chlorine would be liberated. At best the yield of chlor-anilines would be low, and the product impure.

TABLE 7

Normal Sulphuric Acid and Tenth-Normal Aniline

\begin{tabular}{l|c|c|c}
\hline Volts & Amperes $\times$ IO $^{7}$ & Volts & Amperes $\times$ IO $^{7}$ \\
\hline 0.029 & -2.7 & 0.667 & -0.015 \\
$0.1 \mathrm{I}$ & $\mathrm{I} .48$ & $0.7 \mathrm{II}$ & 0.002 \\
$0.2 \mathrm{I}$ & 1.06 & 0.742 & +0.002 \\
0.273 & 0.75 & 0.778 & 0.008 \\
$0.34 \mathrm{I}$ & 0.5 & $0.8 \mathrm{I} 4$ & 0.012 \\
0.374 & 0.347 & 0.847 & 0.02 \\
0.406 & 0.25 & 0.872 & 0.042 \\
0.438 & 0.19 & 0.909 & 0.145 \\
0.479 & 0.132 & 0.941 & 0.8 \\
0.506 & 0.125 & 0.956 & 2.5 \\
0.538 & 0.072 & 0.969 & 7.45 \\
0.577 & 0.039 & 0.948 & I5.5 \\
0.604 & 0.023 & Aniline black commenced to form \\
& & before last reading was made
\end{tabular}

These conclusions are in agreement with the results of an experiment in which roo grams of aniline were dissolved in $45^{\circ}$ cc of hydrochloric acid of s. g. I.2, and electrolyzed with a current of 7.5 amperes for $73 / 4$ hours. The anode was a piece of arc light carbon I I cm long; the cathode platinum $2 \times 5 \mathrm{~cm}$. No chlorine was noticed in the gases given off. The vessel containing the electrolyte was surrounded by an ice-bath, but the temperature rose to $3^{\circ} \mathrm{C}$.

After the electrolysis the dark liquid was filtered and 
evaporated. On cooling, $5^{\circ}$ grams of crystals were deposited, and three days later another crop of fourteen grams was obtained. These crystals, and the final mother-liquor were examined for chlor-aniline by adding caustic soda in excess, extracting with ether, removing the ether on a water-bath, and fractionating the residual oil. The boiling-point rose rapidly to $\mathrm{I} 79^{\circ}$, and all but 4 or $5 \mathrm{Cc}$ passed over at $\mathrm{I} 79^{\circ}-\mathrm{I} 8 \mathrm{I}^{\circ}$, the boiling-point of aniline. The residue contained a little chlorine; thus while chlor-anilines are formed, they amount to but a few percent of the weight of the aniline employed.

\section{Aniline and hydrobromic acid}

As the oxidation potential of aniline ( 0.95 volt) lies above the decomposition voltage of hydrobromic acid ( 0.75 volt in $4-n$ $\mathrm{HBr}$ ), it follows that on electrolysis of a solution of aniline in hydrobromic acid bromine will be liberated, and aniline black will not be formed. This conclusion is confirmed by the following experiment.

$25 \mathrm{~g}$ of potassium bromide, I2.5 cc of pure sulphuric acid, and $0.9 \mathrm{~g}$ of aniline were dissolved in water, the total volume of the solution being $65 \mathrm{cc}$; a precipitate of potassium sulphate was removed by decantation.

TABLE 8

n-Sulphuric Acid, n/ Io $m$-Nitraniline

\begin{tabular}{c|c|c|c}
\hline Volts & Amperes $\times 10^{7}$ & Volts & Amperes $\times 10^{7}$ \\
\hline 0.20 & -1.20 & 1.56 & +3.3 \\
0.21 & 0.27 & 1.59 & 4.0 \\
0.27 & 0.17 & 1.62 & 6.8 \\
0.31 & 0.11 & 1.65 & 9.0 \\
0.41 & 0.02 & 1.69 & 12.0 \\
0.75 & +0.08 & 1.73 & 15.32 \\
0.96 & 0.22 & 1.75 & 18.1 \\
1.27 & 0.30 & 1.76 & 20.4 \\
1.47 & 0.78 & 1.79 & 26.0 \\
1.53 & 1.82 & 1.81 & 29.0 \\
\hline
\end{tabular}

A current of 0.25 ampere was passed through this solution between platinum electrodes (anode $2 \times 5 \mathrm{~cm}$, cathode $2 \times \mathrm{I} \mathrm{cm}$ ) 
for ten minutes. No aniline black was formed, but the anode became covered with a deposit of white matted crystals, stained with bromine. These crystals were removed, washed, and dried and their melting-point found to be $16^{\circ} ; s$-tribrom-aniline melts at $\operatorname{II} 8^{\circ}$.

\section{$m$-Nitraniline}

From chemical considerations it seemed probable that nitraniline would be less easily oxidized than aniline itself. To test this view, a series of experiments analogous to those of Curve IV were undertaken, in which $m$-nitraniline, instead of aniline was dissolved in the sulphuric acid.

The results are plotted in Curve V. The oxidation potential of $m$-11itraniline lies at $\mathrm{I} .43$ volts, 0.2 above the chlorine kink.

\section{Summary}

The conditions under which decomposition-voltages can be determined in acid solutions of aniline are specified (page 54I).

The formation of aniline black from $n /$ ro aniline in solu. tions of $n$-hydrochloric acid or $n$-sulphuric acid takes place at 0.95 volt (small anode, hydrogen cathode).

- Therefore only traces of chlor-aniline are formed on electrolysis of aniline in hydrochloric acid solution; but brom-anilines are formed by the electrolysis of solutions containing hydrobromic acid and aniline. The aniline solutions thus resemble those of phenol. ${ }^{x}$

The oxidation potential of $m$-nitraniline in sulphuric acid solution ( $\mathrm{x} .43$ volts), is much higher than that of aniline.

My thanks are due to Prof. W. Lash Miller, at whose suggestion these measurements were carried out.

\section{University of Toronto,} June, 1907

${ }^{1}$ Zehrlant. Zeit. f. Elektrochem. 7, 5OI (IgOI). 